\title{
Life Skill Education: Enhancing Empowerment among Rural Primary School Children in Gujarat, India
}

Dr Bigi Thomas ${ }^{+*}$ and Chandrik Rajdeep ${ }^{*}$

\section{Abstract}

At a time when there is an unprecedented surge in reported cases of abuses against children in its all forms in India and the legal, social as well as educational system continue to fail in either protecting them or empowering them to face their challenges, it is essential to equip them to learn life skills because such initiatives provide the children with a variety of alternative and creative ways of solving problems of everyday life. In this study, the authors attempt to assess the changes witnessed among rural primary school children after three months of life skill education. Improvement in their communication, participation, perception, values, behaviour, and academic performance was included in the assessment areas.

Activity-based participatory learning techniques like games, role plays, drama, drawing, and reflections were included in the modules of life skills, which were used in teaching them in a nonthreatening atmosphere. The experiential learning method, which gives opportunities to the subjects to have a first-hand encounter with the phenomenon under consideration instead of simply imagining the situation or merely looking into the prospect of doing something about it, helped children to have a clear understanding about these life skills and its applicability in real-life situations. Reflective sessions after hearing, observing, and practicing each skill, enabled children to think loudly about their performances and understanding about each session. Children could learn a lot from others' viewpoints, observations, and ideas too.

Detailed narration with specific activities as well as games practiced, of each module of life skill education taught to children is included in this study. Results proved that there is an improvement in life skills among children in the areas of communication, participation, perceptions, and values after having life skill education.

Keywords: Life Skill Education; Primary School Children; Empowerment; Gujarat; India

\footnotetext{
${ }^{+}$Reader, Department of Social Work, Sardar Patel University, Vallabh Vidyanagar, Gujarat.

${ }^{*}$ Corresponding Author, Email: bigisrsh@gmail.com

* Assistant Professor, Department of Social Work, Sardar Patel University,Vallabh Vidyanagar, Gujarat C2021Thomas \& Rajdeep. This is an Open Access article distributed under the terms of the Creative Commons Attribution License (http://creativecommons.org/licenses/by/2.0), which permits unrestricted use, distribution, and reproduction in any medium, provided the original work is properly cited.
} 


\section{Introduction}

As diverse and nuanced as the country, there are several reasons, ranging from lack of competent teachers to lack of infrastructure facilities and motivation among children, attached to why India's education system is not considered healthy and robust (Singh, 2018). However, one of the crucial reasons for this poor performance is the rote learning method, a flawed teaching methodology still widely used in India, especially in government schools, in which children are made learn the portions by repeatedly doing it (Times of India, 2019). Meaningful learning enables children to understand all concepts with active participation in the learning process and allows them to be constructive and innovative with acquired knowledge. On the contrary, rote learners mug up the lessons without knowing the meaning and understanding of the concepts. Students are merely passive listeners in this form of education instead of being active participants (Oxford Learning, 2017).

It is an indisputable fact that children worldwide are at risk of abuses of all kinds, which is a grave matter of concern for all societies across the globe (Bakir, 2018). A nation that aspires to be a world power must ensure its children's overall development, which can only be ensured by imparting quality education. Nevertheless, the unprecedented rise in the reported cases of child abuse in the recent past is glaring evidence of the education system's failure to equip children with abilities that can help them learn skills and abilities to face challenges in their lives (Chahal \& Kumar, 2017).

The mounting intricacies of life and the dramatic alterations brought about by socio-economic transitions in India have played a key role in escalating children's susceptibility to various and newer forms of cruelty, exploitation, and maltreatment (Singh, 2016). Life of children of all sections in India, with its myriad of social problems like poverty, unemployment, alcoholism, substance abuse, poor health care facilities, consumerism, corruption, violence, lack of good governance, environmental issues, pollution, and malnutrition, is complicated and challenging (Prajapati et al., 2017). The best way to reach out to these most defenceless, weak and voiceless section of the society is the introduction of a challenging education system, through which each child, irrespective of his/her class, creed, religion or culture, would be empowered to grow and develop entirely to his/her fullest potential. The education system's primary purpose should be to create an environment that facilitates the development of various life skills that are essential to cope with the challenges the children confront within everyday life.

A growing body of empirical evidence proved that an intervention program on life skills education among young rural girls has significantly augmented their coping skills and problem-solving ability (Acharya et al., 2009; Chaudhary \& Mehta, 2012; Kackar \& Joshi, 2019; Pujar et al., 2014; Srikala, \& Kishore, 2010). Research conducted by Yadav and Iqbal, (2009) unequivocally confirmed the significant positive impact of life skill education on educational achievement, emotional stability and selfesteem among urban youth from New Delhi.

A plethora of empirical studies (Amirian, 2012; Balasundari \& Benjamin, 2014; Bardhan, 2016; Daisy \& Nair, 2018; Srikala \& Kishore, 2010) has explicitly underlined a significant enhancement, as a result of LSE, in the academic performance as well as the ability to cope up with life challenges and resilience. The enhanced general adjustment reported by their experimental group is evident that LSE programs enable children to be empowered and enhanced persons with the necessary skills to survive in the contemporary world, which has myriad challenges.

The experiential learning method gives opportunities to the subjects to have a first-hand encounter with the phenomenon under consideration instead of simply imagining the situation or merely looking into the prospect of doing something about it (Beaudin \& Quick, 1995), helped children to have a clear understanding about these life skills and its applicability in real-life situations. 
This study is planned to create a body of knowledge to the mounting discussion around the immediate need of life skill education in India by highlighting the evidence of significant improvements among primary school children after having life skill education and to make suggestions towards policies facilitating life skill education and practice in India. This study was conducted in Ravipura, a remote village in Gujarat, India with around 300 families. Their primary source of livelihood includes agriculture and manual labour from which they get meagre income. Hence their standard of living remains low. While the level of substance abuse is high among the villagers, youth spend most of the time doing nothing, and everywhere one can witness a lack of enthusiasm among the villagers. The same lack of interest and motivation was evident among most of the children we started working with. However, we were quite optimistic as the research has explicitly confirmed that life skill education can not only empower adolescents, even from economically backward sections of society (Chaudhary \& Mehta, 2012) but also make them resilient, competent, and emotionally healthy (Joseph \& Thomas, 2017).

\section{Literature Review}

Life skills encompass a wide arange of skills and competencies, and the most widely accepted definition conceptualise life skills as "abilities for adaptive and positive behavior that enable individuals to deal effectively with the demands and challenges of everyday life" (WHO 1997, p. 1). Similarly, Kwauk and Braga (2017) reckons that life skills also facilitates people to "translate knowledge, skills, and attitudes into specific behaviors to cope with, navigate, or transform life's challenges" (as cited in Dupuy et al., 2018, p.1).

Research highlights "adolescence" as a crucial stage in the life span of a human being, popularly known as "transition period from childhood to adulthood" (Hurlock, 2001). Indeed, Hurlock (2001) argues that life skills equip them with ability to navigate through the demands, apprehensions, challenges successfully, and dilemmas associated with it. It is a prerequisite to grow to their fullest potentials and opportunities in life (Jones \& Kahn, 2017).

In the wake of growing concerns around child protection issues, prevalent within families, schools, and communities in the modern world, life skills are found to be most effective in preparing children to be alert, active and resilient (Desai, 2010). The long-term effects of life skill education, acknowledged by parents, teachers \& employers, and well demonstrated by researchers across the world, include improved health, educational attainment, employability, positivity as well as overall wellbeing (Deming, 2017; Evaldesign, 2019; Langford et al., 2015; World Bank, 2013). Life skills positive impact on sexual health outcomes are also clear from public health literature which argues young people with less patriarchal attitudes are less prone to be in tough and violent relations with others, less likely to have multiple sex partners and less likely to have unsafe sex (Population Council, 2009).

\section{Methodology}

This study's authors had undertaken a life skill education program for three months (December 2019 to February 2020). The reason for taking this period was that the school suggested full participation of students, as there were no main exams in between. To undertake the study, twenty children of 7th and 8th standard primary school of Ravipura, a backward village in Anand district, Gujarat were selected and the changes brought out among them in terms of communication, participation, perception, values, behavior and academic performance were assessed. As the sessions were to be taken up in groups, we decided to have only one school. And for using drama in skill education, we needed a school that appreciates the module and co-operates with the schedule of sessions. With these considerations, we decided Ravipura School as our research site.

Even though life skill education is applicable for all ages of children and adolescents, in the opinion of Hodge et al., (2013), the addressed age group in this study is largely 10-18; since children of this age group are adolescents and are susceptible to a host of predicaments 
including psychological and physical, which are, however, preventable.

A qualitative research methodology is being used in this study as it facilitates the researchers to have the richness of depth learning from a few and report the voices of their own participants. Creswel (2016) argued that it also permits us to look at how processes unfold over time with specific individuals by being in the field for a long time and having an in-depth study and narration of the changes found among subjects (Addo \& Eboh 2014; DeCarlo, 2018; Gray, 2018; Hopper, 2011).

The case-study nature of this research allowed us to understand better how their particular setting or context helped the subjects to develop life skills through specially designed clientcentric modules, including games, skits, activities, and drama. Reflections, an integral part of the module, enabled the researcher to have an insight into the level of empowerment attained by the subjects and would have been possible through qualitative research only.

The qualitative research methodology allows the researchers to self-reflect on what they personally bring to a study. "Qualitative researchers are also often acutely aware of how their own preconceptions and presence may affect a situation" (Hopper, 2011, p. 2). This methodology, we think, has the potential to tell us what real impact the LSE program has brought in among the participating children.

The beauty of qualitative research is that it provides a composite understanding of a problem or situation (Gray, 2018, p.1). We hear numerous voices from many participants, gather various perspectives, and develop many themes. In short, qualitative studies represent the intricacy of a situation, an intricacy that does often emulates that of real life. For example, attitude towards gender differentials intricately woven in children's minds from a remote village like Ravipura glared at us like a hard reality during the sessions and reminded us about the need to be vigilant so that the purpose of our games and activities would not go vain.
Qualitative research methodology also gives freedom to researchers to deviate from the predetermined methods/ factors or specific relationships and explore new ones; because the former may not hold true with the people we need to learn from (Creswell, 2016). In the same way, the qualitative research design can indicate the shortcomings of our own assumptions and concepts. With the liberty to redefine the research questions with field data in qualitative research, what is called precision by Becker (1996), researchers can ensure that they are on the right track and not missing valuable information.

\section{Data Collection Methods}

The data collection was conducted with the help of observations, journal entries by students, audio clips of their reflections, photographs of drama games, reflective journals written by researchers, and the testimonies of teachers of our children. Our students were encouraged to write their reflective journals after reflections within the classrooms, which reveal how the improvisation takes place among children. Audios, videos, and photographs of children's activities and conversations are also used as potential tools to portray the enhancement of empowerment that happened among children through life skill education.

As the primary purpose of this study was to enhance the empowerment of primary school children or in other words to bring out notable changes in them by augmenting their life skills, the researcher used action research design in this study. Action research establishes a link between knowledge and social action. The goal of action research is to improve the conditions of the research participants. Esterberg (2002, p.137) states clearly, "at heart, all action researchers are concerned that research not simply contribute to knowledge but also lead to positive changes in people's lives".

In recent times, action research has increasingly been used by scholars who desire to have concrete results that assist the groups they work with. As researchers, we were interested in applying the life skill education among children. This is because we reckoned that applying life 
skill education to their abilities will help them to face all types of challenges, in their everyday lives including social, emotional, and academic, which would help them to grow to their fullest potential.

Action research facilitates a feeling of collective responsibility while results in meaningful interventions by the community. It supports the inherent dignity and innate strengths of marginalised and provides opportunities for resilience (DeCarlo, 2018). The next section discusses the module of life skill education.

\section{The Module of Life Skill Education}

With life skills education in India gaining momentum, numerous entrepreneurs innovate and develop their own approaches to life skills delivery (Singh \& Menon, 2015). However, we used a life skill education module with a clear definition and conceptual framework, which is evident from the way it is modelled by Rawal (2006), as it starts with understanding emotions, then communication and proceed to understanding self and empathy, thus, leading to creative thinking \& problem solving in addition to critical thinking \& decision-making skills.

Some unique features of this module including non-threatening and interactive environment of the drama classes, the anxiety-free learning atmosphere and guaranteed maximum acceptance by children persuaded us to zeroed in on this module for educating life skills among children as they have the magic potential to attract and sustain children in the whole process. In the concluding chapter of her doctoral thesis, Magic Hai-To-Mumkin Hai (Rawal, 2006, p.287-288) asserts that:

[T] he uniqueness of drama is its capacity to act as an agent of change in the children's lives through experiential learning. It offers the students an opportunity to reflect on life experiences and emotions both inside and outside the dramatic event making it a powerful educational experience.

The following section discusses the reflective practices:

\section{Reflective Practices}

Ghaye (2000) proclaims that "reflective practices offer us a way of trying to make sense of the uncertainty in our workplaces and the courage to work competently and ethically at the edge of order and chaos" (p.7). Reflective practice helps researchers evaluate practice, gives insights about the learnings and relates the practice with theory (Boud et al., 2015; Finlay, 2008).

The first step in reflective practice is gaining an overview of all the past experiences that occurred in the whole process of life skill education by students. This is followed by an indepth analysis of the learning and then deciding measures that can be adopted for improving the past performance of an individual (Mann et al., 2009).

We made our students do reflections and encouraged them to write down their reflections, thus, enabling them to think about their learning, what they liked about the activity, why they liked it and facilitated them to relate their leanings in their social, familial, educational, and cultural contexts. As Schon (1983) said by doing reflection-on-action and reflection-in-action, we allowed ourselves to experience wonder, perplexity, or bewilderment in a situation that we found uncertain or unique and sought to build new understandings to shape our action in the unfolding situation. In the next section, we discuss about the drama games.

\section{Drama Games}

It is essential to have a vivacious and energetic environment to inculcate interest among the students while providing life skill education to them. Only with lecturing or one-sided communication, life skills cannot be taught or enhanced. The critical life skills included in this program need experiential learning, and we decided to use the drama games, which are specifically developed by Rawal (2014) for this purpose. At the same time, she suggests drama "democratizes the classroom for the reason that it relies on co-creative input ..... while role play in drama allows the participants to imagine what life is like for another person; even in a situation 
they are not familiar with, thus encouraging empathetic skills" (p. 58-59). Styslinger (2000) also found that when the drama is interwoven into education, it promotes literacy, multiple interpretations, problem-solving, and collaboration.

The results of the study are critically analysed in the following section.

\section{Data Analysis and Findings}

This study aimed to examine life skill education as a way to enhance empowerment among rural primary school children in Gujarat, India. Interviews with a semi-structured tool allowed us to collect the baseline data of each child under study. The data collected through various methods including, journals and reflections by students and researchers, photos, videos \& observatory notes during and after each session were transcribed with a verbatim account of verbal conversations. All data extracts were coded, collated, and the main themes were analysed (Braun \& Clarke, 2006).

This study's results contribute significantly to the understanding of how life skill education can be used to enhance empowerment among primary school children. The methodology used does indeed help children to understand and practice life skills with ease, clarity, and joy. "Life skills education should be designed to enable children to practice skills in demanding situations" (WHO, 1997). Accordingly, the drama was used as an educational tool throughout the program, which in turn, offered children experiential learning, that is, real-world experience and enhancement of skills for each child in an encouraging environment.

While doing so, our intention was not to make children feel wrong or correct their mistakes. Instead, we wanted to allow them understand the complex social realisms they are rooted in and empower them to transform themselves (Rawal, 2014). As a result of three months of life skill education program, children under this study showed promising results, which are relatively far-reaching for children and youth empowerment, which are somewhat positive changes in their lives.
Numerous studies have affirmed this study's findings, which strongly assert the validity of often discussed potentials of life skill education in making substantial positive changes among children (Acharya et al., 2009; Evaldesign, 2019; Kwauk and Braga, 2017; Langford et al., 2015). Bardhan (2016) asserted that students gained tremendously from the life skills programs, based on a qualitative study conducted among school children in New Delhi. This study's findings demonstrated that there was significant improvement in their communication with teachers, conduct with school mates, scholastic achievement, and parental interactions.

Similarly, LSE is effectively used to promote positivity and optimism among adolescents and widely used as a therapeutic strategy for enhancing their psycho-social wellbeing. It helps them improve coping skills, self-confidence, decision making and empathy (Bharath \& Kumar, 2008; Nasheeda et al., 2019; Parvathy \& Pillai, 2015). The striking findings by Chaudhary and Mehta, (2012) also shed further light on the ability of life skill education in augmenting the empowerment of children as they too found that the life skill education not only provided knowledge and information on various skills like decision making, communication, building selfesteem, developing relationships, dealing with conflicts, coping with peer pressure and emotions, but also equipped the adolescents with experiential learning on how to translate their knowledge into practice.

The current study was conceptualised to enhance children's empowerment by augmentation of their life skills in terms of communication, participation, perception, values, behaviour, and academic performance. This could be accomplished through a life skill education program, where there was enough space and scope for children to learn, practice, simulate and reflect on each module of LSE, including understanding emotions, communication, understanding self, empathy, creative thinking, problem-solving, critical thinking and decision making, The results of our study suggest an explicit enhancement in communication, participation, perceptions, and 
values after having life skill education. The thematic analysis based on our observations and reflections of children helped us believe that there is substantial improvement among children. This was corroborated with their teachers' opinion too, who made their opinions based on their interactions and observations. The teachers believe that these children have made considerable changes in almost all areas, especially in participation with improved communication skills in classes. Children are now bold and confident to talk, some of them can even do public speaking, and their participation is now more meaningful with improved concentration and listening skills.

Their perceptions towards values are also significantly improved, for example, the children now believe in equality- that all their classmates are equal and that all of them are human beings. And so, they should refrain from teasing, bullying or discriminating each other on the basis of their colour, appearance, religion, class, caste, or academic performance.

A deep-rooted superiority feeling was demonstrated initially by many boys in this study, probably as suggests by Thomas. et al., (2018, p.21).

due to the special attention, privileges, power and care, boys and men enjoy compared to girls and women in their families from childhood, for example, the habit of having served food, washed clothes, more say and more freedom.

This gender inequity attitude prevailed in the community was the main reason because boys and girls were not ready to play together at the beginning of drama sessions. Nevertheless, the drama games like bodyguard, killer, follow the leader, crossing river and passing the ball along with its' reflective sessions, gave the children ample opportunities to do away with these inhibitions, helped them to understand and realise, to a great extent, the importance of healthy relationships between girls and boys.

\section{Conclusion}

This study, alongside a learner-centric, qualitative, experiential, action research methodology, tried to enhance children's empowerment from India's economically backward village. The findings of this study, for which we worked with the children for around three months continuously in their school in a friendly and protective environment, proved augmentation of skills like communication, participation, perceptions, and values after having life skill education.

Even though notable changes in academic performance and behaviour could not be confirmed among children, partly due to the short period of life skill education as well as the absence of any main academic test the children had undergone during this period, but the remarkable positive changes, we as well as teachers could observe among children are clearing doubts, completing homework, giving answers, helping friends in studies and even playing with children of the opposite gender, are noteworthy considering the facts that cognitive achievement and life skills are strongly interdependent with academic achievements. Simultaneously, life skills do elevate academic accomplishments and educational achievements and demonstrate strong associations with life satisfaction, growth, success, accomplishment, and reduce risky behaviours like violence and drug abuse (Prajapati et al., 2017).

Indeed, life skill education has enormous potential, providing children with a wide range of abilities and skills to deal with the numerous challenges they encounter in their lives. Even after numerous studies confirmed the power of life skill education in enhancing children's empowerment and having been done dispersed efforts around life skills in India, focus on curriculum integration and teacher development remains poor in India (Singh \& Menon, 2015).

Our study's findings recognised that life skill education has the potential to safeguard children from threats and risks of everyday life and perhaps, can act as a proven buffer against their risk-taking behaviours ensuring children's overall development and bright future. So, this study underscores the immediate need to integrate life skill education in all children's course curriculum. Incorporating life skill 
education in the school curriculum, will be an essential contribution in the field of life skill enhancement programs and child development literature. This might help policymakers formulate strategies to implement life skill education throughout India in all academic institutions in general and primary and secondary schools in particular.

\section{References}

Acharya, R., Kalyanwala, S., \& Jejeebhoy, J, S. (2009). Broadening girls' horizons: Effects of a life skills education programme in rural Uttar Pradesh. Population Council.

https://www.issuelab.org/resources/2459/2459 .pdf

Addo, M., \& Eboh, W. O. (2014). Qualitative and Quantitative Research Methods. In R. Taylor (Ed.). The Essentials of Nursing and Healthcare Research. (pp.136-154). Sage.

Amirian, K. (2012). Effect of life skills education on academic achievement of first year high school male students. European Psychiatry, 27(1), 1. https://doi: 10.1016/S09249338(12)75001-0.

Bakır, Z.Z. (2018, June 5). Global report on children. INSAMER.

https://insamer.com/en/global-report-onchildren-2018_1516.html

Balasundari, K.R. \& Benjamin, E.W. (2014). Correlation of life skills and academic achievement of high school students. Indian Journal of Applied research, 4(4), 147-148. https://www.worldwidejournals.com/indianjournal-of-applied-research(IJAR)/fileview/April_2014_1396367579_0f81f_ 44.pdf

Bardhan, A. (2016). Life skills education: A strategy for handling adolescents' risk behavior. IOSR Journal of Humanities and Social Science, 21(7), 92-99. http://doi: 10.9790/08372107059299 www.iosrjournals.org 92

Beaudin, B. P., \& Quick, D. (1995). Experiential Learning: Theoretical Underpinnings, Fort Collins, CO: HI-CAHS.

https://users.ugent.be/ mvalcke/LI_1213/expe riencial_learning.pdf
Becker, H.S. (1996). The epistemology of qualitative research. In R. Jessor, A. Colby, \& R. A. Shweder (Eds.), Ethnography and human development: Context and meaning in social inquiry (pp. 53-71). University of Chicago Press.

Bharath, S., \& Kumar, K.K.V. (2008). Health promotion using life skills education approach for adolescents in schools - development of a model. Journal of Indian Association for Child \& Adolescent Mental Health, 4(1), 5-11. https://files.eric.ed.gov/fulltext/EJ918869.pdf

Boud, D., Keogh, R. and Walker, D. (1985). Promoting reflection in learning: a model. In D. Boud, R. Keogh and D. Walker (Eds.). Reflection: turning experience into learning (pp. 18-40). Routledge.

Braun, V., \& Clarke, V. (2006). Using thematic analysis in psychology. Qualitative Research in Psychology, 3(2), 77-101. http://doi: 10.1191/1478088706qp063oa

Chahal, D. \& Kumar, R. (2017). Educational rights of children: Issues, challenges and solution: Journey of independent India. Educational Quest- An International Journal of Education and Applied Social Sciences, 8(2), 1-6. http://doi: 8. 257. 10.5958/2230-

7311.2017.00061.7.

Chaudhary, S., \& Mehta, B. (2012): Life Skill Education for the economically backward adolescent boys and girls: An intervention programme. International Journal of Social Sciences \& Interdisciplinary Research, 1(5), 6372.

http://indianresearchjournals.com/pdf/IJSSIR/2 012/May/9_IJS_MAY2012.pdf

Creswell, J. W. (2016). 30 essential skills for the qualitative researcher. Thousand Oaks, Sage.

Daisy, P. J., \& Nair, D.R. (2018). An exploratory study on life skills intervention and its impact on the study skills among young adolescents. International Journal of Innovations in Engineering and Technology, 10(3), 14-20. http://ijiet.com/wpcontent/uploads/2018/07/2.pdf

DeCarlo, M (2018). Scientific Inquiry in Social Work. Open Social Work Education: Roanoke, 
$V A$.

https://www.printme1.com/pdf/13a61c3a/Scie ntific\%20Inquiry\%20in\%20Social\%20Work\%20( print\%20for\%20publication).pdf

Deming, D. J. (2017). The growing importance of social skills in the labor market. The Quarterly Journal of Economics, 132(4), 1593-1640. http://doi: 10.1093/qje/qjx022

Desai, M. (2010). A rights-based preventive approach for psychosocial well-being in childhood (1st ed.). Springer. http://doi:10.1007/978-90-481-9066-9

Dupuy, K., Bezu, S., Knudsen, A., Halvorsen, S., Kwauk, C., Braga, A., \& Helyn, K. (2018, June). Life skills in non-formal contexts for adolescent girls in developing countries. CMI. https://www.researchgate.net/publication/324 772313_Life_skills_in_non-

formal_contexts_for_adolescent_girls_in_devel oping_countries

Esterberg, K. G. (2002). Qualitative methods in social research (6th ed.). Boston, MA: McGrawHill.

Evaldesign. (2019, April). Co-creating tools for measuring the impact of life skills on adolescents: Insights from a Scoping Study in India.

http://www.evaldesign.com/uploads/2/3/8/2/2 3823775/report_echidna_evaldesign_v6.0_ab.p df

Finlay, L. (2008, January). Reflecting on 'Reflective practice'. Paper 52, 1-27. Practicebased Professional Learning: The Open University. http://ncsce.net/wpcontent/uploads/2016/10/Finlay-2008Reflecting-on-reflective-practice-PBPL-paper52.pdf

Ghaye, T. (2000) Into the reflective mode: bridging the stagnant moat. Reflectice Practice, 1(1), 5-9.

https://www.researchgate.net/publication/290 809298_Into_the_reflective_mode_bridging_th e_stagnant_moat

Gray, K. (2018, November 27). Why Qualitative Research? Linked in. https://www.linkedin.com/pulse/whyqualitative-research-kevin-gray

Hodge, K., Danish, S., \& Martin, J. (2013).

Developing a Conceptual Framework for Life

Skills Interventions. The Counseling

Psychologist, 41(8), 1125-1152. doi:

org/10.1177/0011000012462073

Hopper, J. (2011, February 11). Why do qualitative research?Methodological. https://methodlogical.wordpress.com/2011/02 /16/why-do-qualitative-research/

Hurlock, E. B. (2001). Developmental Psychology: A Life Span Approach (5th ed.). Tata McGraw-Hill Education.

Jones, S.M., \& and Kahn, J. (2017, September 13). The Evidence Base for How We Learn: Supporting Students' Social, Emotional, and Academic Development. National Commission on Social, Emotional and Academic Development, The ASPEN Institute. https://assets.aspeninstitute.org/content/uploa ds/2017/09/SEAD-Research-Brief-

9.12_updated-web.pdf

Joseph, D., \& Thomas, B. (2017). Life skills development training for adolescent girls at risk-rescued devadasi girls in Karnataka. ArthaJournal of Social Sciences, 16(1), 1-16.

http://doi: 10.12724/ajss.40.1

Kackar, A., \& Joshi, H. (2019). Impact of life skills among adolescents: A review. International Journal of Research and Analytical Reviews, 6(2), 592-595.

http://ijrar.com/upload_issue/ijrar_issue_2054 3579.pdf

Kwauk, C., \& Braga, A. (2017). Translating competencies to empowered action: $A$ framework for linking girls' life skills education to social change. Center for Universal Education. https://www.brookings.edu/wpcontent/uploads/2017/11/translatingcompetencies-empowered-action.pdf

Langford, B. H., Badeau, S. H., \& Legters, L. (2015). Investing to improve the well-being of vulnerable youth and young adults:

Recommendations for policy and practice. Youth Transition Funders Group. 
http://www.ytfg.org/wpcontent/uploads/2015/11/Investing-in-WellBeing-small.pdf

Mann, K., Gordon, J., \& Macleod, A. (2009). Reflection and reflective practice in health Professions education: A systematic review. Advances in Health Sciences Education: Theory and Practice. 14(4), 595-621.

http://doi:10.1007/s10459-007-9090-2

Nasheeda, A., Abdullah, H.B., Steven Eric Krauss, E. S., \& Ahmed, N.B. (2019). A narrative systematic review of life skills education: effectiveness, research gaps and priorities, International Journal of Adolescence and Youth, 24(3), 362- 379. http://doi:

10.1080/02673843.2018.1479278

Oxford Learning. (2018, March 23). The difference between rote learning and meaningful learning. https://www.oxfordlearning.com/differencerote-learning-meaningful-learning/

Parvathy, V., \& Pillai, R. R. (2015). Impact of life skills education on adolescents in rural school. International Journal of Advanced Research, 3(2), 788-794.

https://www.researchgate.net/publication/308 368929_Impact_of_life_skills_education_on_ad olescents_in_rural_school

Prajapati, R., Sharma, B., \& Sharma, D. (2017). Significance of life skills education.

Contemporary Issues in Education Research, 10(1), 1-6.

https://files.eric.ed.gov/fulltext/EJ1126842.pdf

Population Council (2009). It's all one curriculum: Guidelines and activities for a unified approach to sexuality, gender, HIV, and human rights education. The International Sexuality and HIV Curriculum Working Group, New York.

https://www.popcouncil.org/uploads/pdfs/201 1PGY_ItsAllOneGuidelines_en.pdf

Pujar, L., Hunshal, H., \& Bailur, K. (2014). Impact of intervention on life skill development among adolescent girls. Karnataka Journal of Agricultural Sciences, 27(1), 93-94. http://14.139.155.167/test5/index.php/kjas/art icle/viewFile/7097/7315

Rawal, S. (2006). The role of drama in enhancing life skills in children with specific learning difficulties in a Mumbai school: My reflective account. Doctoral thesis, Coventry University in collaboration with University of Worcester. https://www.actionresearch.net/living/rawal.sh $\mathrm{tml}$

Rawal, S. (2014). Making Magic, Educational. Journal of Living Theories, 7(1), 53-81. https://ejolts.net/node/226

Singh, J. (2018, November 26). Why rural India still has poor access to quality education? Financial Express. https://www.financialexpress.com/education2/why-rural-india-still-has-poor-access-toquality-education/1393555/

Srikala, B., \& Kishore, K. K.V. (2010):

Empowering adolescents with life skills education in schools - School mental health program: Does it work? Indian Journal of Psychiatry, 52(4), 344-349.

http://www.indianjpsychiatry.org/text.asp?201 0/52/4/344/74310

Styslinger, M. E. (2000). Relations of power in education: the teacher and Foucault. Journal of Educational Thought, 34(2), 183-199. https://www.jstor.org/stable/23767233?seq=1

Thomas, B., Trivedi, H. P., Subhash, R., \& Pathak, S. N. (2018). Who perpetrates violence on own spouses? Evidence from India.

Proceedings of the 4th World Conference on Women's Studies, 3 (1), 16-24. doi: 10.17501/wcws.2018.3102

Times of India. (2019). Immediate changes needed in the Indian education system. https://www.indiatoday.in/educationtoday/featurephilia/story/7-immediatechanges-needed-in-the-indian-educationsystem-1579167-2019-08-09

World Health Organization (1997). Life skills education for children and adolescents in schools. WHO Manuscript. Division of Mental Health and Prevention of Substance Abuse. https://apps.who.int/iris/bitstream/handle/106 
65/63552/WHO_MNH_PSF_93.7A_Rev.2.pdf;js essionid=14562D69AD2ECE14913856455C9B99 $6 \mathrm{D}$ ? sequence $=1$

World Bank (2013). Life skills: what are they, why do they matter, and how are they taught? http://documents.worldbank.org/curated/en/5 69931468331784110/Life-skills-what-are-theywhy-do-they-matter-and-how-are-they-taught Yadav, P., \& Iqbal, N. (2009). Impact of Life Skill Training on Self-esteem, Adjustment and Empathy among Adolescents. Journal of the Indian Academy of Applied Psychology, 35, 6170.

https://www.researchgate.net/publication/312 119543_Impact_of_Life_Skill_Training_on_Selfsteem_Adjustment_and_Empathy_among_Adol escents_Pooja_Yadav_and_Naved_lqbal

\section{Conflict of Interest Statement}

None

\section{Acknowledgement Statement}

Both the authors express their deep gratitude to the Department of Social Work, Sardar Patel University, Gujarat for providing necessary support to undertake this study. Also feel thankful to the children and teachers of Ravipura village for their participation in the study. Authors are highly obliged and thankful to the anonymous reviewers for their sincere and positive comments which helped in shaping the manuscript.

\section{Author Contribution Statement}

Dr. Bigi Thomas(corresponding author): Conceptualisation; collecting references; developing the first draft with the incorporation of new ideas and relevant resources writing the first draft; re-writing the final draft; final reviewing of the draft and final editing.

Mr. Chandrik Rajdeep: Conceptualisation; Collecting references; initial reviewing and cross-checking for references; assistance in editing and reviewing of final draft. 